\title{
Very Early Recurrence Juvenile Granulosa Cell Tumor of the Ovary: A Case Report
}

\section{Çok Erken Nüks Eden Overin Juvenil Granuloza Hücreli Tümörü: Olgu Sunumu}

\author{
Ayșe Demirci ${ }^{1}$, İbrahim Türker ${ }^{1}$, Nazan Bozdoğan ${ }^{2}$, Havva Yeşil Çınkır ${ }^{1}$, Kübra Aydın $^{1}$, \\ Füsun Ardıç Yükrük ${ }^{2}$, Berna Öksüzoğlu ${ }^{1}$ \\ ${ }^{1}$ Dr. A. Y. Ankara Onkoloji Eğitim Ve Araştırma Hastanesi, Tıbbi Onkoloji Kliniği, Ankara \\ ${ }^{2}$ Dr. A. Y. Ankara Onkoloji Eğitim Ve Araştırma Hastanesi, Patoloji Kliniği, Ankara, Türkiye
}

Doi: 10.5505/aot.2012.33042

\section{ÖZET}

Overin granüloza hücreli tümörü tüm over malignitelerinin $\% 2-5$ 'ini, juvenil granüloza hücreli tümör ise granuloza hücreli tümörlerin \%5'ini oluşturmaktadır. Genellikle puberte öncesi dönemde ve genç kadınlarda karşımıza çıkar. Erken evrede tanı alırsa iyi gidişlidir fakat ileri evrede tanı aldığında daha agresif bir seyir göstermektedir. Burada 23 yaşında tanı alan evre $1 \mathrm{~A}$ olmasına rağmen postoperatif 2 . ayında nükseden overin juvenil granuloza hücreli tümörü tanılı bir olguyu sunduk.

Anahtar Kelimeler: Granuloza hücreli tümör; Juvenil; Over; Rekürrens

\section{ABSTRACT}

Granulosa cell tumors of the ovary constitute $2-5 \%$ of all ovarian malignancies and juvenile subtypes of granulosa cell tumors constitute $5 \%$ of the granulosa cell tumors. We usually face with juvenile granulosa cell tumor in the early stages of puberty and in young women. Disease course is better with the diagnosis in early stages but it shows aggressive behavior when diagnosed at an advanced stage. We present 23 years old case with stage 1 juvenile granulosa cell tumor that have a recurrence in the second months of operation.

Anahtar Kelimeler: Granuloza hücreli tümör, Juvenil; Over; Rekürrens

\section{Giriş}

Overin granüloza hücreli tümörü (GHT) tüm over malignitelerinin \%2-5'ini oluşturmaktadir (1). Erişkin ve juvenil olarak iki alt tipi vardır. Juvenil granüloza hücreli tümör (JGHT) tüm GHT'lerin \%5'ini oluşturmaktadır, genellikle puberte öncesi genç kadınlarda karşımıza çıkar (2). Erken evrede tanı alırsa iyi gidişlidir, ileri evrede tanı aldığında daha agresif bir seyir göstermektedir (3). Histopatolojik olarak, erişkin tipte daha nadir görülen makrofoliküler ya da kistik patern JGHT'de görülür ve JGHT'deki immatür granüloza hücrelerinde daha fazla mitoz vardır, Call-Exner cisimcikleri ile çentikli kahve çekirdeği görünümü pek sık değildir (4). Burada nadir görülmesi ve hızlı nüks etmesi nedeniyle overin JGHT tanılı bir olguyu sunduk.

\section{Olgu sunumu}

Adress for correspondence: Uzm. Dr. Ayse Demirci, Ankara Onkoloji Eăitim Araștrrma Hastanesi e-mali:aaysedemirci@gmail.com

Available at www.actaoncologicaturcica.com
Yirmi üç yaşında kadın hasta karın ağrısı şikayeti ile başvurduğunda yapılan abdominal ultrasonografisinde saptanan sağ over kisti nedeniyle kist eksizyonu yapıldı. Patolojisi malign mikst germ hücreli tümör olarak raporlanan hastada ameliyattan 3 hafta sonra şiddetli karın ağrısı gelişmesi üzerine over torsiyonu ön tanısı ile acil operasyona alınmış. Eksplorasyonda uterus, sol tuba ve sol over doğal görünümde, sağ over 5 cm'lik görünümde olup $2 \mathrm{kez}$ kendi etrafinda torsiyone olarak izlenmişti. Hastaya fertilite isteği de göz önünde bulundurularak sağ salpingooferektomi, bilateral pelvik paraaortik lenf nodu diseksiyonu, omentum biyopsisi ve sol ovarian biyopsi ve batın içi yıkama işlemi yapıld1. Mikroskopik olarak 2 ayrı merkezde incelenen patoloji örneklerinde endometrial stromal sarkom, JGHT ve rabdomyosarkom arasında ayrım yapılamadı. Lenf nodlarının 
hepsi reaktif, omentum ve y1kama s1v1s1 tümörsüz olan hasta erken evre olarak kabul edildi fakat tümörün tipi net olmadığından tam evresi belirtilemedi. Hasta bu sonuçlarla Tıbbi Onkoloji kliniği'ne başvurdu.

Fizik muayenesinde karında operasyon skarı ve hafif hassasiyeti dışında anormallik yoktu. Hastamızın özgeçmişinde puberte prekoks semptom ve bulguları yoktu. Hastanın ECOG performans durumu sifir idi. Laboratuar tetkiklerinde tam kan sayımı, biyokimyasal parametreleri, AFP ve $\beta$ HCG normal, CA125: $106 \mathrm{U} / \mathrm{ml}$ (0-35) olarak yüksek saptand.
Patoloji blokları merkezimizde tekrar incelendiğinde ve mikroskopisinde over dokusu içerisinde yer yer kistik yer yer de solid alanlar gösteren tümöral oluşum, miksoid stromada yerleşmiş küçük ve orta boy hücrelerden oluşan, arada dağınık multinükleer dev hücreler ve sik mitoz içeren tümör izlendi (Resim 1,2). İmmünhistokimyasal olarak WT1 ile yaygin (Resim 3), desmin ile fokal paranükleer boyanma tespit edildi. Innhibin, PLAP, EMA, Pan CK, MyoD1, kalretinin, CD99, LCA, miyogenin, kaldesmon ve aktin ile boyanma olmadı. Bu sonuçlara göre hastaya JGHT tanısı kondu.

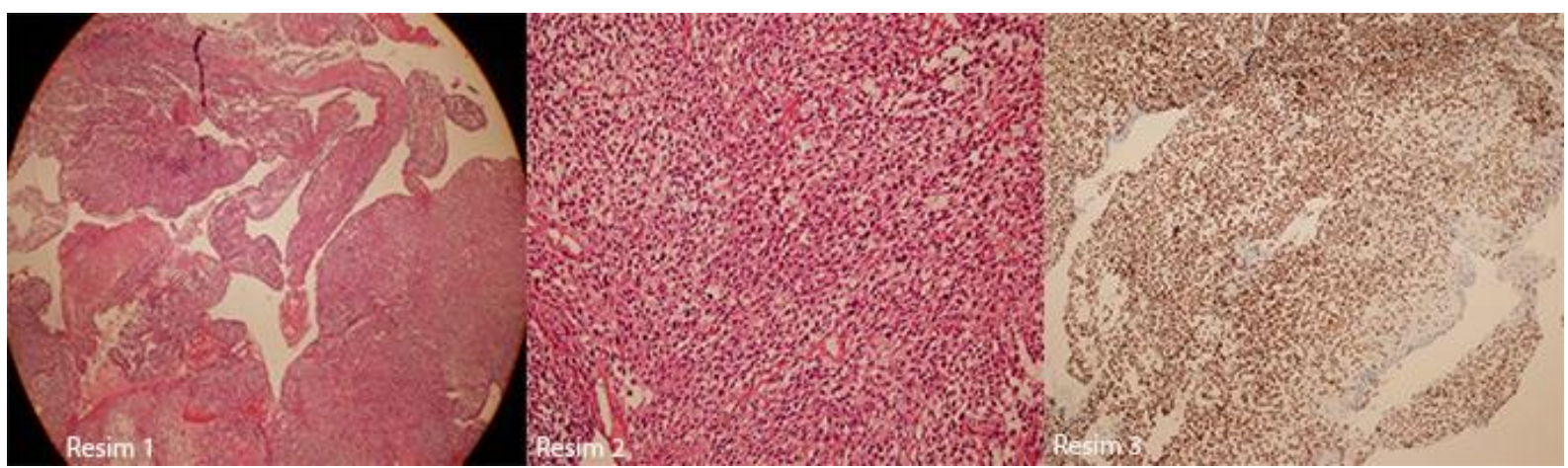

Resim 1: Kistik yapılar HEX100, 2: Miksoid stromada küçük orta boy hücrelerden oluşan tümör HEX200,

3: Tümör hücrelerinin WT -1 ile boyanması X200

Hastanın postoperatif 2. ayda yapilan tetkiklerinden abdominal manyetik rezonans görüntüleme (MRG) ve pozitron emisyon tomografi- bilgisayarlı tomografisinde (PETBT) abdomende nüks kitleleri izlendi. MRG'de karın içinde multipl birbiriyle birleşme eğiliminde en büyük yerinde $12 \mathrm{~cm}$ ölçülen kitleler saptandı. PET-BT'de büyüğü pelvis girişinde $8.5 \mathrm{~cm}$ olan konglemere kitlelerinde patolojik artmış FDG tutulumu gözlendi (Resim 4). Hastaya neoadjuvan kemoterapi olarak bleomisin (30 mg/gün 1, 8 ve 15 . günler), etoposit $\left(100 \mathrm{mg} / \mathrm{m}^{2} /\right.$ gün $1-5$. günlerde), sisplatin (20 $\mathrm{mg} / \mathrm{m}^{2} /$ gün $1-5$. günlerde) (BEP) 3 kür verilip operasyon için tekrar değerlendirilmesine karar verildi. Üç kür BEP kemoterapisi sonrası karın ağrısı, karında şişkinlik gibi şikayetlerinde gerileme oldu. Yapilan kontrol abdominal MRG'de kitlelerinin en uzun çap1 $12 \mathrm{~cm}$ idi. Görüntüleme yöntemleri ile tümör boyutlarında hafif büyüme olmasına rağmen klinik olarak semptomlarda düzelme izlendi. CA125 düzeyi $22 \mathrm{U} / \mathrm{ml}$ 'ye geriledi. Jinekoloji tarafindan operasyon planlanan hastaya operasyon için bekleme süreci içerisinde bir kür daha kemoterapi verildi. Hasta nüks sonrası evre $3 \mathrm{C}$ olması nedeniyle planlandığ 1 şekilde interval debulking için jinekolojiye yönlendirildi.

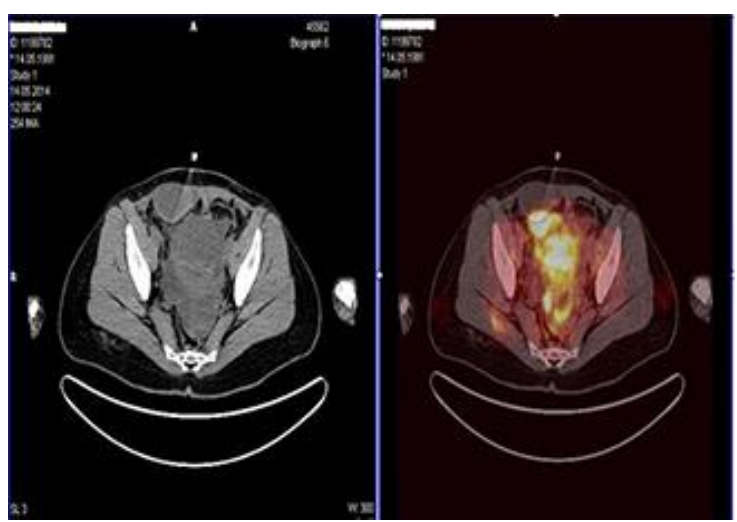

Resim 4: Büyüğü pelvis girişinde $8.5 \mathrm{~cm}$ olmak üzere birbiri ile birleşme eğiliminde abdomen pelvik ve peritoneal yüzeylerde yer yer hipodens alanlar içeren septalı yumuşak doku alanlarında SUVm: 9.76 olan FDG tutulumu (PET-BT).

Hastaya debulking cerrahisi yapıldı fakat çocuk isteği olduğu için sol ooferektomi ve 
histerektomi yapılmadi. Postoperatif patolojisi mesane, sigmoid kolon, rektum, omentum, sağ arteria ve vena ovarika ve sağ üreter üstü bölgerinde yaygın kemoterapi etkileri gösteren tümör alanları izlendi. Çıkarılan 15 lenf nodunun hiçbirinde tümör yoktu. Hastaya adjuvan tedavide luteinizan hormon releasing hormon (LHRH) analoğu başlandı.

\section{Tartışma}

JGHT çoğu zaman östrojen sekresyonuna bağl1 meme büyümesi, pubik ve aksiller k1llanma, vajinal sekresyon, düzensiz uterin kanama ve diğer sekonder seks karakterlerinin gelişmesi gibi puberte prekoks bulguları ile ve erken evrede tanı alır. Nadiren karın ağrısı gibi şikayetlerle de tanı alabilir (5). Literatürde enkondromatozis ve Mafucci sendromu ile birlikteliği dikkati çekmektedir (6). Bizim olgumuzda östrojen sekresyonu ile ilgili bulgular yoktu. Hastalar genellikle puberte öncesi dönemde ve yaşamın ilk 2 dekadında tanı alır (7). Sunduğumuz hasta da 23 yaşında tanı almıştır.

GHT'de serum östradiol, inhibin, müllerian inhibitör substans (MIS) düzeyleri tümör belirteçleri olarak yükselebilir. GHT'de östradiol düzeyi tüm hastalarda takip açısından güvenilir bir belirteç değildir. İnhibin normal koşullarda granüloza hücrelerinden sekrete edilen folikül stimüle edici hormon (FSH) için negatif feedback etkisi olan bir hormondur (3). Hem JGHT hem de erişkin GHT'lerde inhibin düzeyleri yüksek saptanabilir (8). Fakat inhibin düzey yüksekliği GHT'ler için spesifik değildir, özellikle müsinöz over kanserlerinde de yüksek saptanabilir (9). MİS düzeyi ile ilgili çalışmalar deneysel düzeydedir. Olgumuzda inhibin düzeyi çalışılmamıştır. Operasyon sonras1 2. ayda bakılan CA125 düzeyi yüksek geldiği için 3 kür kemoterapi sonrası CA125 tekrar bakıld1 ve gerilediği gözlendi. İlk bakılan CA125 düzeyinin yüksek olmasının nedeni geçirdiği abdominal operasyona bağlı olabilir. JGHT tanısında serum AFP ve beta HCG düzeylerinin ölçümü germ hücreli tümörlerin dışlanması açısından önemlidir. Hastamızın ilk patolojisi germ hücreli tümör lehinde değerlendirilmesine rağmen başvuru anından itibaren bu belirteçler normal sinırlardaydi.

JGHT iyi seyirli ve sessiz bir gidişe sahiptir. Erişkin tipe göre daha az diferansiye olmasına karşın kür oranı daha yüksektir. Evre en önemli prognostik faktördür. Genellikle erken evrede tanı alır ve bu durumda iyi bir gidiş gösterirler. Fakat FIGO evre II, III ya da IV hastalarda daha agresif bir gidiş görülebilir (3). Literatüre göre evre I hastalarda 5 yıllık sağ kalım oranları \%90'ların üzerindedir (10). Young ve ark.'nın çalıșmasında 95 JGHT'li hastanın \%91'i 5 y1llik takip sonrasında nükssüz takip edilmektedir (7). Bizim olgumuz tanıda evre IA olmasina ve optimal cerrahi operasyon yapılmasına rağmen 2 ay sonrasında hızla nüks etmiştir. Literatürde erken evrede olmasina rağmen bu kadar erken nükseden olgu saptanmamıştır. Zaloudek ve Norrisin çalışmasında en erken nüks 3 ayda, Vassal ve ark.'nın serisinde 6. ayda ve Yaung ve ark.'nın serisinde ise 7 ayda saptanmıştır $(7,11,12)$.

JGHT'nin tedavisi ile ilgili literatürde yeterli veri yoktur. Bilinen temel tedavisi cerrahidir (7). Genellikle fertilite isteği de göz önünde bulundurularak tek taraflı salpingooferektomi uygulanmaktadır (3). Kemoterapi ileri evre ve nüks hastalıkta uygulanabilir ve iyi sonuçlar elde edilir. İleri evre ve nüks hastalık ile ilgili platin temelli kemoterapiler ile genel yanit oranlar1 \%63-80 arasındadır (13). Schneider ve ark.'nın yaptığ 1 çalışmada evre II ve üzeri JGHT tanılı hastaların uzun dönem takip sonuçları yayınlanmıştır. $\mathrm{Bu}$ çalışmada adjuvan tedavi verilen yaşları 4-18 arasında değişen 7 hasta incelenmiştir. $\mathrm{Bu}$ hastaların üçü evre IIC, bir tanesi evre IIIA, üçü evre IIIC idi. Hastaların hepsine 4-6 kür sisplatin temelli kemoterapi verilmiş ve multipl periton metastazı olan bir hastaya radyoterapi verilmiş. Hastaların hepsinde adjuvan tedaviler sonrası tam klinik remisyon elde edilmiş. Ortanca 47 (15-138) aylık takip sonuçlarına göre hastaların dördünde tümör rekürrensi görülmezken, birinde 126. ayda karşı overde nüks, birinde 12. ayda tümör rekürrensi görülüp tekrar sisplatin içeren kemoterapi uygulanmış ve tam yanıt elde edilmiş. Diğer hastada ise tam yanıt elde edildikten sonra yaygın peritoneal nüks ile masif asit gelişmiş ve hasta tümör progresyonundan dolayı kaybedilmiştir. $\mathrm{Bu}$ çalışmanın sonuçlarına göre hem adjuvanda hem de nükste sisplatin temelli kemoterapilerin JGHT'li hastalarda etkin olduğu gösterilmiştir (14). Literatürde JGHT'nin tedavisinde taksan/ platin kombinasyonu, sisplatin/ siklofosfamid/ etoposit/ bleomisin kombinasyonu verilen 
olgular bildirilmiştir. Myeloablatif kemoterapi (karboplatin/ etoposit/ melfalan) verilip otolog kemik iliği transplantasyonu yapılan ve nüksünden sonra 69 ay tam remisyonda takip edilen pediatrik olgu vardır. Radyoterapinin de nüks JGHT'lerde sağkalıma katkısı olduğu gösterilmiştir $(3,14,15)$. Olgumuz nüksetmesi sonras1 platin temelli (BEP) kemoterapi ile tedavi edilmiştir ve operasyona gönderilmiştir.

Sunduğumuz olgu karın ağrısı ile tetkik edilip tanı almıştır. İlk operasyonunda evre 1A olmasına rağmen hizla nüks etmesi açısından ilginçtir. Nüks etmesi nedeniyle neoadjuvan BEP kemoterapisi sonras1 debulking cerrahisi yapılmış ve postoperatif adjuvan LHRH analoğu başlanmıştır.

\section{Çıkar Çatışması: Yok}

\section{Kaynaklar}

1. Young RH. Sex cord-stromal tumors of the ovary and testis: their similarities and differences with consideration of selected problems. Mod Pathol 2005;18Suppl 2:S81-93

2. Lack EE, Perez-Atayde AR, Murthy AS, et al. Granulosa theca cell tumors in premenarchal girls: a clinical and pathologic study of ten cases. Cancer 1981;48:1846-54

3. Colombo N, Parma G, Zanagnolo V, Insinga A. Management of ovarian stromal cell tumors. J Clin Oncol 2007:25:2944-51

4. Boyce EA, Costaggini I, Vitonis A, et al. The epidemiology of ovarian granulosa cell tumors: a case-control study. Gynecol Oncol 2009;115:221-5
5. Schumer ST, Cannistra SA. Granulosa cell tumor of the ovary. J Clin Oncol 2003;21:1180-9

6. Rietveld L, Nieboer TE, Kluivers KB, et al. First case of juvenile granulosa cell tumor in an adult with Ollier disease. Int J Gynecol Pathol 2009;28:464-7

7. Young RH, Dickersin GR, Scully RE. Juvenile granulosa cell tumor of the ovary. A clinicopathological analysis of 125 cases. Am J Surg Pathol 1984;8:575-96

8. Kurihara S, Hirakawa T, Amada S, Ariyosh K, Nakano H. Inhibin-producing ovarian granulosa cell tumor as a cause of secondary amenorrhea: case report and review of the literatüre. J Obstet Gynaecol Res 2004;30:439-43

9. Healy DL, Burger HG, Mamers P, et al. Elevated serum inhibin concentrations in postmenopausal women with ovarian tumors. $\mathrm{N}$ Engl $\mathrm{J}$ Med 1993;329:1539-42

10. Zanagnolo V, Pasinetti B, Sartori E. Clinical review of 63 cases of sex cord stromal tumors. Eur J Gynaecol Oncol 2004;25:431-8

11. Zaloudek C, Norris HJ: Granulosa tumors of the ovary in children. Am J Surg Pathol 1982;6:503-12.

12. Vassal G, Flamant F, Caillaud JM, Demeocq F, Nihoul-Fekete C, Lemerle J. Juvenile granulosa cell tumor ofthe ovary in children:a clini cal study of 15 cases. J Clin Oncol 1988;6:990-5

13. Schneider DT, Calaminus G, Wessalowski R, Pathmanathan R, Harms D, Göbel U. Therapy of advanced ovarian juvenile granulosa cell tumors. Klin Padiatr 2002;214:173-8

14. Hirakawa M, Nagai Y, Yagi C, Nashiro T, Inamine M, Aoki Y. Recurrent juvenile granulosa cell tumor of the ovary managed by palliative radiotherapy. Int $\mathbf{J}$ Gynecol Cancer 2008;18:913-5

15. Erdreich-Epstein A, Monforte HL, Lavey RS, Joshi S, Phillips JD, Villablanca JG. Successful multimodality therapy ofrecurrentmultifocal juvenile granulosa cell tumor of the ovary. J Pediatr Hematol Oncol 2002;24:229-33 